www.nature.com/ja

\title{
Absolute stereochemistry of pentacecilides, new inhibitors of lipid droplet formation in mouse macrophages, produced by Penicillium cecidicola FKI-3765-1
}

\author{
Hiroyuki Yamazaki, Narihiro Ugaki, Daisuke Matsuda and Hiroshi Tomoda
}

The structure of a new pentacecilide congener, pentacecilide D, produced by Penicillium cecidicola FKI-3765-1 was elucidated by various NMR experiments. The absolute stereochemistry of pentacecilides was elucidated by using the modified Mosher method for pentacecilide C. The inhibitory activity of all pentacecilides against lipid droplet formation and acyl-CoA:cholesterol acyltransferase isozymes was compared.

The Journal of Antibiotics (2010) 63, 315-318; doi:10.1038/ja.2010.39; published online 23 April 2010

Keywords: absolute stereochemistry; acyl-CoA:cholesterol acyltransferase; fungal metabolite; lipid droplet formation; Penicillium cecidicola; pentacecilides D

\section{INTRODUCTION}

As we reported previously, pentacecilides A to C (Figure 1) were isolated from the whole culture of Penicillium cecidicola FKI-3765-1 as inhibitors of lipid droplet formation in mouse macrophages. ${ }^{1,2}$ From the biochemical study, ${ }^{1}$ pentacecilides inhibited lipid droplet formation in mouse macrophages, probably due to the blockade of acyl-CoA:cholesterol acyltransferase (ACAT) activity. Furthermore, pentacecilides appeared as dual inhibitors of ACAT1 and ACAT2 isozymes. ${ }^{1,3-7}$ The structures including the relative stereochemistry were also elucidated; ${ }^{2}$ however, the indication of the relative stereochemistry at C-2 was revised ${ }^{8,9}$ because erroneous structures of pentacecilides had been shown in our previous reports. ${ }^{1,2}$ Further precise analysis of metabolites in the whole culture led to the discovery of a new congener named pentacecilide D (Figure 1). In this study, the structure of the new pentacecilide congener was elucidated. Furthermore, the absolute stereochemistry of pentacecilides was determined by using the modified Mosher method ${ }^{10}$ for pentacecilide C.

\section{RESULTS}

\section{Isolation of pentacecilide $\mathrm{D}$}

The 13-day-old whole culture $(1000 \mathrm{~g})$ was extracted with 2.01 of acetone. After the acetone extracts were filtered and concentrated to remove acetone, the aqueous solution was extracted with ethyl acetate. The extracts were dried over $\mathrm{Na}_{2} \mathrm{SO}_{4}$ and concentrated in vacuo to dryness to yield a red-brown material $(1.7 \mathrm{~g})$. The material was dissolved in $30 \% \mathrm{CH}_{3} \mathrm{CN}$, applied to an octadecyl silyl (ODS) column chromatography $(100 \mathrm{~g})$, and eluted stepwise with $30,50,70,100 \%$
$\mathrm{CH}_{3} \mathrm{CN}$ containing $0.050 \%$ trifluoroacetic acid $(250 \mathrm{ml} \times 2$ tubes for each solvent). Pentacecilides $\mathrm{A}$ and $\mathrm{B}$ were present in the first tube of $100 \% \mathrm{CH}_{3} \mathrm{CN}$. The first tube of $70 \% \mathrm{CH}_{3} \mathrm{CN}$ containing pentacecilides $\mathrm{C}$ and $\mathrm{D}$ was concentrated in vacuo to dryness to give a red-brown material. The material $(172 \mathrm{mg}$ ) was finally purified by preparative HPLC (column, PEGASIL ODS, $20 \times 250 \mathrm{~mm}$; Senshu Scientific, Tokyo, Japan; solvent, $55 \% \mathrm{CH}_{3} \mathrm{CN}$ containing $0.050 \%$ trifluoroacetic acid; detection, $\mathrm{UV}$ at $210 \mathrm{~nm}$; flow rate, $8.0 \mathrm{ml} \mathrm{min}^{-1}$ ). Under these conditions, pentacecilides $\mathrm{C}$ and $\mathrm{D}$ were eluted as peaks with retention times of 15.8 and $25.8 \mathrm{~min}$, respectively. The respective fractions were concentrated in vacuo to dryness to give pure pentacecilides C (56.6 mg) and D (5.1 mg) as white crystals.

Structural elucidation of pentacecilide D

The physicochemical properties of pentacecilide D are summarized in Table 1. Pentacecilide D showed UV absorption maxima at 219, 276 and $310 \mathrm{~nm}$, similar to pentacecilides A to C. ${ }^{2}$ IR absorption at 3426 and $1712-1617 \mathrm{~cm}^{-1}$ suggested the presence of hydroxy and carbonyl groups in the structure.

The molecular formula was determined to be $\mathrm{C}_{25} \mathrm{H}_{32} \mathrm{O}_{7}$ on the basis of HRESI-TOF-MS measurement, indicating that pentacecilide $\mathrm{D}$ was smaller than pentacecilide C. ${ }^{2}$ The ${ }^{13} \mathrm{C}$ NMR spectrum (in $\mathrm{CDCl}_{3}$ ) showed 25 resolved signals, which were classified into five methyl carbons, four methylene carbons, two $s p^{3}$ methine carbons, one $s p^{2}$ methine carbon, three oxygenated $s p^{3}$ methine carbons, two $s p^{3}$ quaternary carbons, one oxygenated $s p^{3}$ quaternary carbon, three $s p^{2}$ quaternary carbons, two oxygenated $s p^{2}$ quaternary carbons and two 


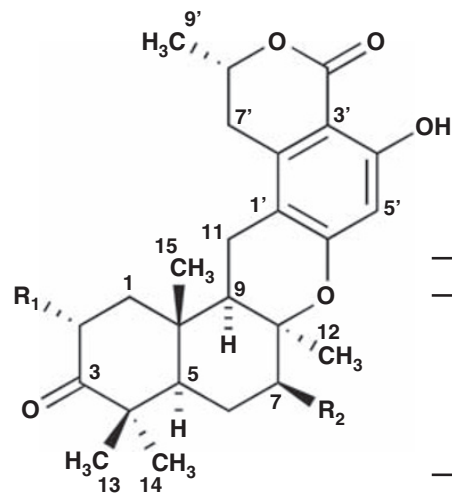

Figure 1 Structures of pentacecilides A-D.

Table 1 Physicochemical properties of pentacecilide D

\begin{tabular}{ll}
\hline & Pentacecilide $D$ \\
\hline Appearance & White crystaline solid \\
Molecular weight & 444 \\
Molecular formula & $\mathrm{C}_{25} \mathrm{H}_{32} \mathrm{O}_{7}$ \\
& \\
HRESI-TOF-MS $(\mathrm{m} / z)$ & \\
$\quad$ Calcd: & $445.2226(\mathrm{M}+\mathrm{H})^{+}$ \\
$\quad$ Found: & $445.2216(\mathrm{M}+\mathrm{H})^{+}$ \\
$\mathrm{UV}(\mathrm{MeOH}) \lambda_{\max }, \mathrm{nm}(\varepsilon)$ & $219(34800), 276(24700), 310(11800)$ \\
{$[\alpha]_{D}^{26}$} & $-51.4^{\circ}(c 0.10, \mathrm{CHCl})$ \\
IR $(\mathrm{KBr}) v_{\max }\left(\mathrm{cm}^{-1}\right)$ & $3426,1712,1666,1617,1473$ \\
\hline
\end{tabular}

carbonyl carbons by analysis of the DEPT and HSQC spectra. The ${ }^{1} \mathrm{H}$ NMR spectrum (in $\mathrm{CDCl}_{3}$ ) displayed 30 proton signals, one of which was suggested to be a hydroxy proton $(\delta$ 11.09). Taking the molecular formula into consideration, the presence of two hydroxy protons was suggested. The connectivity of proton and carbon atoms was established by the ${ }^{13} \mathrm{C}-{ }^{1} \mathrm{H}$ HSQC spectrum (Table 2). These spectral data from NMR and physicochemical properties showed that pentacecilide D has the same skeleton as pentacecilide C. ${ }^{2}$ Comparison of the ${ }^{1} \mathrm{H}$ NMR spectra between pentacecilides $\mathrm{C}$ and $\mathrm{D}$ indicated that the methyl proton signals $(\mathrm{C}-17, \delta 2.17)$ derived from the acetyl group in pentacecilide $\mathrm{C}$ disappeared from pentacecilide $\mathrm{D}$. In addition, the chemical shift of C-2 ( $\delta 69.9)$ and the molecular formula showed the presence of a hydroxy group at C-2. These data led to the conclusion that the structure of pentacecilide $\mathrm{D}$ was 2-deacetyl pentacecilide $\mathrm{C}$ (Figure 1). The structure satisfied the degree of unsaturation and the molecular formula.

Regarding the relative stereochemistry of pentacecilide D, NOESY experiments were carried out showing coupling constants in ${ }^{1} \mathrm{H}$ NMR similar to pentacecilide C. ${ }^{2,8,9}$ Accordingly, the relative stereochemistry of pentacecilide D was elucidated as shown in Figure 1.

\section{Absolute stereochemistry of pentacecilides}

To elucidate the absolute stereochemistry of pentacecilides, the $(S)$ (1) and (R)- $\alpha$-methoxy- $\alpha$-(trifluoromethyl)phenylacetyl (MTPA) esters (2) were prepared by treatment of pentacecilide $C$ with $(R)$ $(-)$ - and $(S)-(+)-$ MTPA chloride in the presence of 4-(dimethylamino) pyridine and triethylamine (in $\mathrm{CH}_{2} \mathrm{Cl}_{2}$, at room temperature, 80.6 and $61.5 \%$ yield, respectively) (Scheme 1 ). The ${ }^{1} \mathrm{H}$ NMR spectra of 1 and 2 were completely assigned. As shown in Figure 2, the
Table $2{ }^{1} \mathrm{H}$ and ${ }^{13} \mathrm{C}$ NMR chemical shifts of pentacecilide D

\begin{tabular}{|c|c|c|}
\hline \multirow[b]{2}{*}{ No. } & \multicolumn{2}{|c|}{ Pentacecilide D } \\
\hline & $\partial_{C}$ & $\partial_{H}(J$ in $H z)$ \\
\hline \multirow[t]{2}{*}{1} & 44.9 & $1.60 \mathrm{~m}$ \\
\hline & & $2.38 \mathrm{~m}$ \\
\hline 2 & 69.9 & $4.64 \mathrm{~m}$ \\
\hline 3 & 214.8 & - \\
\hline 4 & 47.6 & - \\
\hline 5 & 46.4 & $1.80 \mathrm{~m}$ \\
\hline \multirow[t]{2}{*}{6} & 26.6 & $1.86 \mathrm{~m}$ \\
\hline & & $2.18 \mathrm{~m}$ \\
\hline 7 & 71.8 & $4.13 \mathrm{dd}(10.0,3.0)$ \\
\hline 8 & 79.2 & - \\
\hline 9 & 43.4 & $2.21 \mathrm{~m}$ \\
\hline 10 & 36.0 & - \\
\hline 11 & 21.5 & $2.52 \mathrm{~m}$ \\
\hline 12 & 20.9 & $1.23 \mathrm{~s}$ \\
\hline 13 & 20.9 & $1.20 \mathrm{~s}$ \\
\hline 14 & 25.4 & $1.19 \mathrm{~s}$ \\
\hline 15 & 23.9 & $1.54 \mathrm{~s}$ \\
\hline $1^{\prime}$ & 110.9 & - \\
\hline $2^{\prime}$ & 139.4 & - \\
\hline $3^{\prime}$ & 103.6 & - \\
\hline $4^{\prime}$ & 162.4 & - \\
\hline $5^{\prime}$ & 103.6 & $6.34 \mathrm{~s}$ \\
\hline $6^{\prime}$ & 159.1 & - \\
\hline \multirow[t]{2}{*}{$7^{\prime}$} & 31.9 & $2.71 \mathrm{dd}(17.0,11.0)$ \\
\hline & & $2.84 \mathrm{dd}(17.0,3.5)$ \\
\hline $8^{\prime}$ & 74.7 & $4.64 \mathrm{~m}$ \\
\hline $9^{\prime}$ & 20.9 & $1.56 \mathrm{~d}(7.0)$ \\
\hline $10^{\prime}$ & 170.0 & - \\
\hline $4^{\prime}-\mathrm{OH}$ & & $11.09 \mathrm{~s}$ \\
\hline
\end{tabular}

calculated $\Delta \delta$ values $\left(\Delta \delta=\delta_{S}-\delta_{R}\right)$ of $\mathrm{H}_{2}-11, \mathrm{H}_{3}-12, \mathrm{H}-5^{\prime}$ and $\mathrm{H}-8^{\prime}$ were positive, whereas those $\left(\Delta \delta=\delta_{S}-\delta_{R}\right)$ of $\mathrm{H}_{2}-1, \mathrm{H}-2, \mathrm{H}-5 \mathrm{H}_{2}-6$, $\mathrm{H}-9, \mathrm{H}_{3}-13, \mathrm{H}_{3}-14, \mathrm{H}_{3}-15$ and $\mathrm{H}_{3}-17$ were negative, indicating that the absolute stereochemistry of C-7 was elucidated to be $7 S$. Accordingly, the absolute stereochemistry of the seven chiral centers in pentacecilide $\mathrm{C}$ was concluded to be $2 R 5 R 7 S 8 R 9 R 10 S 8^{\prime} S$, as shown in Figure 1. It is plausible that all pentacecilides are biosynthesized by the same pathway; therefore, the absolute stereochemistry of the other pentacecilides was deduced to be the same as that of pentacecilide $\mathrm{C}$ (Figure 1).

\section{Biological properties}

Inhibition of CE synthesis in macrophages and ACAT1- and ACAT2$\mathrm{CHO}$ cells. In the previous study, pentacecilides inhibited cholesteryl ester (CE) synthesis in mouse macrophages and ACAT1- and ACAT2$\mathrm{CHO}$ cells, strongly suggesting that they were dual inhibitors of ACAT1 and ACAT2 isozymes. ${ }^{1}$ Pentacecilide D and semisynthetic $3 S^{*}$-hydroxy pentacecilide A (3) were evaluated in these three cellbased assays, and the $\mathrm{IC}_{50}$ values of $\mathrm{CE}$ synthesis were compared. Pentacecilide A is the most potent inhibitor of CE synthesis in the three assays, followed by pentacecilide B. ${ }^{1}$ Unfortunately, pentacecilides D and 3 showed almost no inhibitory activity at $22.5-24.2 \mu \mathrm{M}$.

No pentacecilides showed any cytotoxic effects on macrophages and ACAT1- and ACAT2-CHO cells, even at 20.6-24.3 $\mu \mathrm{M}$. 
<smiles>CC(=O)O[C@H]1C[C@@]2(C)[C@@H](C[C@H](O)[C@@]3(C)Oc4cc(O)c5c(c4C[C@@H]32)CC[C@@H](C)OC5=O)C(C)(C)C1=O</smiles>

Pentacecilide C

Pentacecilide A
(R)-(-)-(S)-(+)-MTPA chloride DMAP, TEA, $\mathrm{CH}_{2} \mathrm{Cl}_{2}$

r.t, 10h

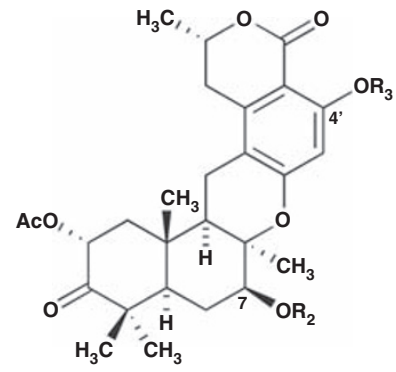

1: $R_{2}, R_{2}=(S)-(+)-M T P A$ 2: $\mathrm{R}_{2}, \mathrm{R}_{3}=(R)-(-)-\mathrm{MTPA}$<smiles>C[C@H]1Cc2c3c(cc(O)c2C(=O)O1)O[C@@]1(C)CCC2C(C)(C)C(=O)CC[C@]2(C)[C@@H]1C3</smiles>

$\underset{\mathrm{NaBH}_{4}, \mathrm{CH}_{3} \mathrm{OH}}{\longrightarrow}$<smiles>C[C@@H]1Cc2c3c(cc(O)c2C(=O)O1)O[C@]1(C)CCC2C(C)(C)[C@H](O)CC[C@]2(C)[C@@H]1C3</smiles>

Scheme 1 Semisynthetic preparation of 1-3.

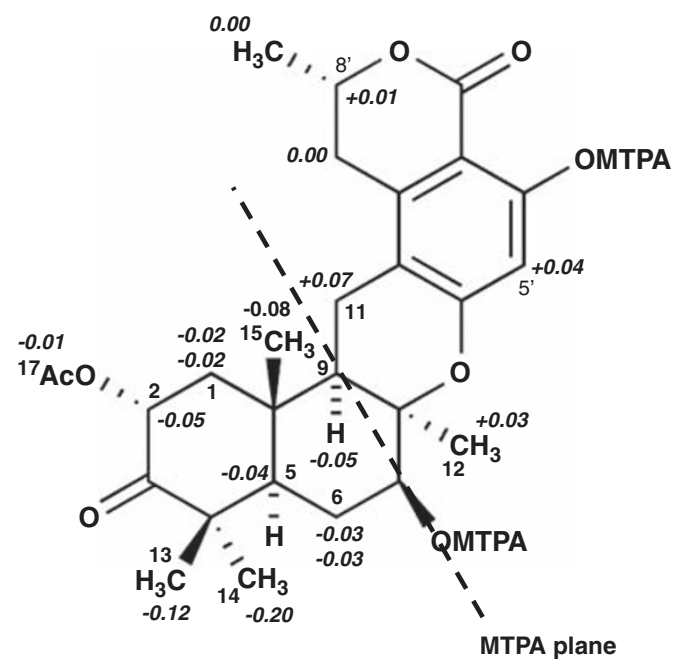

Figure 2 Absolute stereochemistry determination. $\Delta \delta$ values ( $\Delta \delta$ (in p.p.m.)= $\delta_{S}-\delta_{R}$ ) obtained for di-Mosher esters $\mathbf{1}$ and $\mathbf{2}$.

\section{DISCUSSION}

As described above, from various spectral analyses, the structure of a new congener, pentacecilide $\mathrm{D}$, was elucidated to be 2-deacetyl pentacecilide $\mathrm{C}$ with the same relative stereochemistry as shown in Figure 1.

To determine the absolute stereochemistry of pentacecilides, the modified Mosher method ${ }^{10}$ was adapted to pentacecilide C. Calculation of the $\Delta \delta$ values led to the clear conclusion that pentacecilide $\mathrm{C}$ has the absolute stereochemistry of $2 R 5 R 7 S 8 R 9 R 10 S 8^{\prime} S$ (Figure 1). Furthermore, assuming that all pentacecilides are generated through the same biosynthetic pathway, pentacecilides A, B and D have the same absolute stereochemistry as pentacecilide C. This
Table 3 Effects of pentacecilides on cholesteryl ester synthesis in macrophages, and ACAT1- and ACAT2-CHO cells

\begin{tabular}{lccc}
\hline & \multicolumn{3}{c}{ IC $50(\mu \mathrm{M})$} \\
\cline { 2 - 4 } Pentacecilide & Macrophages & ACAT1-CHO & ACAT2-CHO \\
\hline A & 3.65 & 1.09 & 0.69 \\
B & 4.76 & 10.8 & 3.97 \\
C & $>20.6$ & $>20.6$ & $>20.6$ \\
D & $>22.5$ & $>22.5$ & $>22.5$ \\
3 & $>24.2$ & $>24.2$ & 19.0 \\
\hline
\end{tabular}

conclusion was supported by evidence that all pentacecilides have negative optical rotations. ${ }^{2}$

In a cell-based assay using mouse macrophages, ACAT1- and ACAT2-CHO cells, ${ }^{11-13}$ pentacecilides A and B showed more potent inhibition of CE synthesis than pentacecilides $C$ and $\mathrm{D}^{1}$ (Table 3 ). Furthermore, 3 showed no inhibition of $\mathrm{CE}$ synthesis in mouse macrophages, and ACAT1- and ACAT2-CHO cells, even at $24.2 \mu \mathrm{M}$ (Table 3). Taking the structural differences into consideration (Figure 1), the presence of a hydroxy group at C-7 is unfavorable for inhibiting lipid droplet formation and ACAT activity. Regarding the C-3 position, 3 with a hydroxy group at C-3 showed weaker inhibitory activity than pentacecilide $\mathrm{A}$, indicating that the presence of a carbonyl group at C-3 is important for activity. Regarding the C-2 position, introduction of acethoxy and hydroxy groups resulted in decreased activity. Namely, no modification at this position is preferable for inhibitory activity. Among these pentacecilides, it was concluded that pentacecilide A has the most favorable structure for showing potent inhibitory activity against lipid droplet formation and ACAT isozymes. Regarding the structure-activity relationships of 
the hydroxy group at C-4', synthesis of acyl derivatives at this position is now in progress.

\section{METHODS}

\section{Materials}

$(S)-(+)$ - and $(R)-(-)$-MTPA chlorides, and sodium borohydride $\left(\mathrm{NaBH}_{4}\right)$ were purchased from Wako Pure Chemical Industries (Osaka, Japan). Acetic anhydride $\left(\mathrm{Ac}_{2} \mathrm{O}\right)$ and 4-(dimethylamino) pyridine were purchased from Kanto Chemical (Tokyo, Japan). Triethylamine was purchased from Nacalai Tesque (Kyoto, Japan).

\section{General experimental procedures}

Fungal strain P. cecidicola FKI-3765-1 was used for the production of pentacecilides. ${ }^{1,2}$ Pentacecilide D was from 13-day-old culture broth fermented as reported previously. ${ }^{1}$ For determination of the amounts of pentacecilide D in culture broths, samples (ethyl acetate extracts) dissolved in methanol were analyzed by the HP1100 system (Hewlett-Packard, Palo Alto, CA, USA) under the following conditions: column, Symmetry $(2.1 \times 150 \mathrm{~mm}$; Waters, Milford, MA, USA); flow rate, $0.2 \mathrm{ml} \mathrm{min}^{-1}$; mobile phase, a 20 -min linear gradient from $60 \% \mathrm{CH}_{3} \mathrm{CN}$ to $100 \% \mathrm{CH}_{3} \mathrm{CN}$ containing $0.050 \% \mathrm{H}_{3} \mathrm{PO}_{4}$; detection, UV at $210 \mathrm{~nm}$. Under these conditions, pentacecilide $\mathrm{D}$ was eluted with a retention time of $3.59 \mathrm{~min}$, respectively.

SSC-ODS-7515-12 (Senshu Scientific) was used for ODS column chromatography. HPLC was carried out using the L-6200 system (Hitachi, Tokyo, Japan).

UV spectra were recorded on a spectrophotometer (8453 UV-Visible spectrophotometer; Agilent Technologies, Santa Clara, CA, USA). IR spectra were recorded on a Fourier transform infrared spectrometer (FT-710; Horiba, Kyoto, Japan). Optical rotations were measured with a digital polarimeter (DIP-1000; JASCO, Tokyo, Japan). ESI-TOF-MS and HRESI-TOF-MS spectra were recorded on a mass spectrometer (JMS-T100LP; JEOL, Tokyo, Japan). Various NMR spectra were measured with a spectrometer (XL-400; Varian, Palo Alto, CA, USA).

\section{Preparation of the $(S)-(+)$ - and $(R)-(-)$-MTPA ester derivatives of pentacecilide $\mathrm{C}$}

To a solution of pentacecilide $\mathrm{C}(5.0 \mathrm{mg}, 0.010 \mathrm{mmol})$ in $\mathrm{CH}_{2} \mathrm{Cl}_{2}(500 \mu \mathrm{l})$, $(R)-(-)$-MTPA chloride $(16.5 \mathrm{mg}, 0.065 \mathrm{mmol}), 4$-(dimethylamino) pyridine $(5.3 \mathrm{mg}, 0.043 \mathrm{mmol})$ and triethylamine $(10 \mu \mathrm{l}, 0.073 \mathrm{mmol})$ were added. The reaction mixture was stirred at room temperature. After $10 \mathrm{~h}$, the reaction mixture was diluted with $1.0 \mathrm{~N} \mathrm{HCl}$ and the aqueous phase was extracted with EtOAc. The organic layer was recovered, dried over anhydrous $\mathrm{Na}_{2} \mathrm{SO}_{4}$, filtered and concentrated in vacuo to dryness. The product was purified by preparative HPLC (column; PEGASIL ODS, $20 \times 250 \mathrm{~mm}$; Senshu Scientific; solvent, $80 \%$ $\mathrm{CH}_{3} \mathrm{CN}$; detection, $\mathrm{UV}$ at $210 \mathrm{~nm}$; flow rate, $\left.8.0 \mathrm{ml} \mathrm{min}^{-1}\right)$ to give $\mathbf{1}(7.40 \mathrm{mg}$, $0.0081 \mathrm{mmol}, 80.6 \%)$ as a white powder. Similarly, $2(4.63 \mathrm{mg}, 0.0050 \mathrm{mmol}$, $61.5 \%)$ was obtained using $(S)-(+)$-MTPA chloride.

7, $4^{\prime}-(S)-(+)$ - $\alpha$-methoxy- $\alpha$-(trifluoromethyl)phenylacetoxy pentacecilide $\mathrm{C}$ (1): ${ }^{1} \mathrm{H}$ NMR $\left(400 \mathrm{MHz}, \mathrm{CDCl}_{3}\right) \delta 1.05(\mathrm{~s}, 3 \mathrm{H}), 1.06(\mathrm{~s}, 3 \mathrm{H}), 1.10(\mathrm{~s}, 3 \mathrm{H}), 1.36$ (s, 3H), $1.52(\mathrm{~d}, 3 \mathrm{H}, J=7.0 \mathrm{~Hz}), 1.68,2.28(\mathrm{~m}, 2 \mathrm{H}), 1.85,2.14(\mathrm{~m}, 2 \mathrm{H}), 2.17$ $(\mathrm{s}, 3 \mathrm{H}), 2.57(\mathrm{~m}, 2 \mathrm{H}), 2.74,2.82(\mathrm{dd}, 2 \mathrm{H}, J=17.0,11.0 \mathrm{~Hz}, J=17.0,3.5 \mathrm{~Hz}), 3.52$ $(\mathrm{s}, 3 \mathrm{H}), 3.73(\mathrm{~s}, 3 \mathrm{H}), 4.58(\mathrm{~m}, 1 \mathrm{H}), 5.54(\mathrm{~m}, 1 \mathrm{H}), 5.56(\mathrm{~m}, 1 \mathrm{H}), 6.35(\mathrm{~s}, 1 \mathrm{H})$, $7.26(\mathrm{~m}, 3 \mathrm{H}), 7.44(\mathrm{~m}, 3 \mathrm{H}), 7.52(\mathrm{~m}, 2 \mathrm{H}), 7.75(\mathrm{~m}, 2 \mathrm{H})$; HRESI-TOF-MS $(\mathrm{m} / z)$ found: 941.2935 , calcd: $941.2948[\mathrm{M}+\mathrm{Na}]^{+}$for $\mathrm{C}_{47} \mathrm{H}_{48} \mathrm{~F}_{8} \mathrm{NaO}_{12}$.

7, $4^{\prime}-(R)-(-)-\alpha$-methoxy- $\alpha$-(trifluoromethyl)phenylacetoxy pentacecilide $\mathrm{C}$ (2): ${ }^{1} \mathrm{H}$ NMR (400 MHz, $\left.\mathrm{CDCl}_{3}\right) \delta 1.14(\mathrm{~s}, 3 \mathrm{H}), 1.17(\mathrm{~s}, 3 \mathrm{H}), 1.30(\mathrm{~s}, 3 \mathrm{H}), 1.33$ $(\mathrm{s}, 3 \mathrm{H}), 1.53(\mathrm{~d}, 3 \mathrm{H}, J=7.0 \mathrm{~Hz}), 1.87,2.16(\mathrm{~m}, 2 \mathrm{H}), 2.31(\mathrm{~m}, 2 \mathrm{H}), 2.17(\mathrm{~s}, 3 \mathrm{H})$, $2.50(\mathrm{~m}, 2 \mathrm{H}), 2.74,2.82(\mathrm{dd}, 2 \mathrm{H}, J=17.0,11.0 \mathrm{~Hz}, J=17.0,3.5 \mathrm{~Hz}), 3.53(\mathrm{~s}, 3 \mathrm{H})$, $3.76(\mathrm{~s}, 3 \mathrm{H}), 4.57(\mathrm{~m}, 1 \mathrm{H}), 5.60(\mathrm{~m}, 1 \mathrm{H}), 5.61(\mathrm{~m}, 1 \mathrm{H}), 6.31(\mathrm{~s}, 1 \mathrm{H}), 7.32(\mathrm{~m}$, $3 \mathrm{H}), 7.44(\mathrm{~m}, 3 \mathrm{H}), 7.52(\mathrm{~m}, 2 \mathrm{H}), 7.74(\mathrm{~m}, 2 \mathrm{H})$; HRESI-TOF-MS $(\mathrm{m} / \mathrm{z})$ found: 941.2980, calcd: $941.2948[\mathrm{M}+\mathrm{Na}]^{+}$for $\mathrm{C}_{47} \mathrm{H}_{48} \mathrm{~F}_{8} \mathrm{NaO}_{12}$.

\section{Preparation of $3 S^{*}$-Hydroxy-pentacecilide A}

To a solution of pentacecilide A $(2.9 \mathrm{mg}, 0.0070 \mathrm{mmol})$ in $\mathrm{CH}_{3} \mathrm{OH}(500 \mu \mathrm{l})$, $\mathrm{NaBH}_{4}(3.3 \mathrm{mg}, 0.087 \mathrm{mmol})$ was added, and the resulting solution was stirred at room temperature. After $10 \mathrm{~h}$, the reaction mixture was diluted with $\mathrm{H}_{2} \mathrm{O}$ and the aqueous phase was extracted with EtOAc. The organic layer was recovered, dried over anhydrous $\mathrm{Na}_{2} \mathrm{SO}_{4}$, filtered and concentrated in vacuo to dryness. The product was purified by preparative HPLC (column; PEGASIL ODS, $20 \times 250 \mathrm{~mm}$; Senshu Scientific; solvent, $80 \% \mathrm{CH}_{3} \mathrm{CN}$; detection, UV at $210 \mathrm{~nm}$; flow rate, $\left.8.0 \mathrm{ml} \mathrm{min}^{-1}\right)$ to give $3(2.5 \mathrm{mg}, 0.0060 \mathrm{mmol}, 85.7 \%)$ as a white powder.

$3 S^{*}$-Hydroxy-pentacecilide A (3): ${ }^{1} \mathrm{H}$ NMR $\left(400 \mathrm{MHz}, \mathrm{CDCl}_{3}\right) \delta 0.86$ $(\mathrm{s}, 3 \mathrm{H}), 1.02(\mathrm{~s}, 3 \mathrm{H}), 1.09(\mathrm{~s}, 3 \mathrm{H}), 1.26(\mathrm{~m}, 1 \mathrm{H}), 1.29(\mathrm{~s}, 3 \mathrm{H}), 1.46,1.56$ $(\mathrm{m}, 2 \mathrm{H}), 1.55(\mathrm{~d}, 3 \mathrm{H}, J=6.0 \mathrm{~Hz}), 1.66,1.80(\mathrm{~m}, 2 \mathrm{H}), 1.70(\mathrm{~m}, 2 \mathrm{H}), 1.76$ $(\mathrm{m}, 1 \mathrm{H}), 2.00,2.08(\mathrm{~m}, 2 \mathrm{H}), 2.40(\mathrm{~m}, 2 \mathrm{H}), 2.68,2.85(\mathrm{dd}, 2 \mathrm{H}, J=17.0,11.0 \mathrm{~Hz}$, $J=17.0,3.5 \mathrm{~Hz}), 3.26(\mathrm{dd}, J=10.0,4.0 \mathrm{~Hz}, 1 \mathrm{H}), 4.63(\mathrm{~m}, 1 \mathrm{H}), 6.26(\mathrm{~s}, 1 \mathrm{H}), 11.0$ $(\mathrm{s}, 1 \mathrm{H})$; HRESI-TOF-MS $(\mathrm{m} / \mathrm{z})$ found: 437.2290 , calcd: $437.2304[\mathrm{M}+\mathrm{Na}]^{+}$for $\mathrm{C}_{25} \mathrm{H}_{34} \mathrm{NaO}_{5}$.

\section{Biological assays}

An assay for the synthesis of $\mathrm{CE}$, triacylglycerol and phospholipids by mouse macrophages was carried out according to the method described previously. ${ }^{11}$ An assay for ACAT1 and ACAT2 activities in ACAT1- and ACAT2-CHO cells was carried out by our established method. ${ }^{12,13}$

\section{ACKNOWLEDGEMENTS}

This study was supported in part by a Sasakawa Scientific Research Grant (to HY) from The Japan Science Society. We express our thanks to Ms N Sato for NMR experiments, and Dr K Nagai and Ms A Nakagawa for measuring mass spectra.

1 Yamazaki, $\mathrm{H}$. et al. Pentacecilides, new inhibitors for lipid droplet formation in mouse macrophages produced by Penicillium cecidicola FKI-3765-1:I. Taxonomy, fermentation, isolation and biological properties. J. Antibiot. 62, 195-200 (2009).

2 Yamazaki, H., Ōmura, S. \& Tomoda, H. Pentacecilides, new inhibitors for lipid droplet formation in mouse macrophages produced by Penicillium cecidicola FKI-3765-1:II. Structure elucidation. J. Antibiot. 62, 207-211 (2009).

3 Chang, C. C., Huh, H. Y., Cadigan, K. M. \& Chang, T. Y. Molecular cloning and functional expression of human acyl-coenzyme A:cholesterol acyltransferase cDNA in mutant Chinese hamster ovary cells. J. Biol. Chem. 268, 20747-20755 (1993).

4 Anderson, R. A. et al. Identification of a form of acyl-CoA:cholesterol acyltransferase specific to liver and intestine in nonhuman primates. J. Biol. Chem. 273, 2674726754 (1998)

5 Cases, S. et al. ACAT-2, a second mammalian acyl-CoA:cholesterol acyltransferase. Its cloning, expression, and characterization. J. Biol. Chem. 273, 26755-26764 (1998).

6 Oelkers, P., Behari, A., Cromley, D., Billheimer, J. T. \& Sturley, S. L. Characterization of two human genes encoding acyl coenzyme A:cholesterol acyltransferase-related enzymes. J. Biol. Chem. 273, 26765-26771 (1998).

7 Parini, P. et al. ACAT2 is localized to hepatocytes and is the major cholesterolesterifying enzyme in human liver. Circulation 110, 2017-2023 (2004).

8 Corrigenda. J. Antibiot. 62, 651 (2009).

9 Corrigenda. J. Antibiot. 62, 653-654 (2009).

10 Ohtani, I., Kusumi, T., Kashman, Y. \& Kakisawa, H. High-field FT NMR application of Mosher's method. The absolute configuration of marine terpenoids. J. Am. Chem. Soc. 113, 4092-4096 (1991).

11 Namatame, I., Tomoda, H., Arai, H., Inoue, K. \& Ōmura, S. Complete inhibition of mouse macrophage-derived foam cell formation by triacsin C. J. Biochem. 125, 319-327 (1999).

12 Lada, A. T. et al. Identification of ACAT1- and ACAT2-specific inhibitors using a novel, cell-based fluorescence assay: individual ACAT uniqueness. J. Lipid. Res. 45, 378-386 (2004).

13 Ohshiro, T., Rudel, L. L., Ōmura, S. \& Tomoda, H. Selectivity of microbial acyl-CoA: cholesterol acyltransferase inhibitors toward isozymes. J. Antibiot. 60, 43-51 (2007). 